\title{
Retraction Note: Association of severity of coronary artery disease by SYNTAX score (SS) and lower extremity arterial disease by duplex ultrasound (DUS) study—an Indian perspective
}

Saumen Nandi ${ }^{1}$, Anindya Mukherjee ${ }^{1 *}$, Dibbendhu Khanra ${ }^{2}$ and Kaushik Biswas ${ }^{1}$

Retraction Note: Egypt Heart J 72, 56 (2020)

https://doi.org/10.1186/s43044-020-00091-z

The Editor-in-Chief has retracted this article [1]. Following publication, the journal was notified that the published article reports an extension of study originally conducted between 1st May 2017 to 31st July 2018; the authors have confirmed that further ethics approval was not sought for the extension of the study.

All authors agree to this retraction.

\section{Author details}

'Department of Cardiology, NRS Medical College, Kolkata, India. ${ }^{2}$ Heart and Lung Centre, New Cross Hospital, Royal Wolverhampton NHS Trust, Heath

Town, Wolverhampton, UK.

Published online: 29 December 2020

\section{Reference}

1. Nandi S, Mukherjee A, Khanra D et al (2020) Association of severity of

coronary artery disease by SYNTAX score (SS) and lower extremity arterial disease by duplex ultrasound (DUS) study — an Indian perspective. Egypt Heart J 72:56. https://doi.org/10.1186/s43044-020-00091-z

* Correspondence: anindya768@yahoo.co.in

${ }^{1}$ Department of Cardiology, NRS Medical College, Kolkata, India

Full list of author information is available at the end of the article

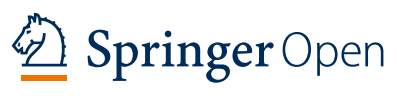

(๑) The Author(s). 2021 Open Access This article is licensed under a Creative Commons Attribution 4.0 International License which permits use, sharing, adaptation, distribution and reproduction in any medium or format, as long as you give appropriate credit to the original author(s) and the source, provide a link to the Creative Commons licence, and indicate if changes were made. The images or other third party material in this article are included in the article's Creative Commons licence, unless indicated otherwise in a credit line to the material. If material is not included in the article's Creative Commons licence and your intended use is not permitted by statutory regulation or exceeds the permitted use, you will need to obtain permission directly from the copyright holder. To view a copy of this licence, visit http://creativecommons.org/licenses/by/4.0/. 